\title{
NEW ISOFLAVONES, INHIBITING CATECHOL-O-METHYLTRANSFERASE, PRODUCED BY STREPTOMYCES
}

\author{
Hideo Chimura, Tsutomu Sawa, Yoshiki Kumada, Hiroshi Naganawa, \\ Meiki Matsuzaki, Tomohisa Takita, Masa Hamada, \\ Tomio Takeuchi and Hamao Umezawa \\ Institute of Microbial Chemistry, \\ Kamiosaki, Shinagawa-ku, Tokyo, Japan \\ (Received for publication June 4, 1975)
}

\begin{abstract}
In the screening of catechol-O-methyltransferase inhibitors in streptomyces culture filtrates, three new isoflavones were isolated. Their structures were shown to be 3', 5,7-trihydroxy-4', 6-dimethoxyisoflavone (I), $3^{\prime}, 5,7$-trihydroxy-4', 8-dimethoxyisoflavone (II), 3', 8-dihydroxy-4',6,7-trimethoxyisoflavone (III). I and II inhibited both catechol-O-methyltransferase and dopa decarboxylase, and showed hypotensive action. III was a specific inhibitor of catechol-O-methyltransferase, and showed no hypotensive action.
\end{abstract}

In 1958, AXELRoD and ToMCHICK ${ }^{1)}$ found an enzyme system which catalyses the transfer of the methyl group from S-adenosylmethionine to one of the phenolic hydroxyl groups of epinephrine and other catechols, and the enzyme has been purified from rat and human liver ${ }^{2 \sim 4)}$. This enzyme reaction is involved in extraneural inactivation of norepinephrine, and the inhibition of this route of catecholamine metabolism has been the subject of considerable research interest. Thus inhibitors found in various known compounds have been studied ${ }^{5,6)}$. We were interested in the biological activity of specific inhibitors of this enzyme especially their effect on blood pressure and we screened the activity of culture filtrates of microorganisms in inhibiting this enzyme. In previous papers ${ }^{7,8)}$, we reported isolation of methylspinazarin and dihydromethylspinazarin from streptomyces and isolation from fungi of 7-O-methylspinochrome B and 6-(3-hydroxy-n-butyl)-7-O-methylspinochrome B which inhibit catechol-O-methyltransferase. In this paper, we report the isolation of isoflavone compounds inhibiting this enzyme from streptomyces. The action of one of them was specific to this enzyme and did not show hypotensive effect on spontaneously hypotensive rats.

The method described by Nikodejevic et al. ${ }^{9)}$ was employed to determine the activity of streptomyces culture filtrates in inhibiting catechol-O-methyltransferase. Then, addition of 0.05 $\mathrm{ml}$ of a twice diluted culture filtrate of Streptomyces roseolus (ISP 5174) to the reaction mixture for the enzyme assay showed a significant inhibition. The activity was produced in media containing one of various carbon sources and plant nitrogen sources such as soybean meal, cotton seed meal or corn steep liquor. The following medium was selected as one of suitable media for the production: glucose $1.0 \%$, starch $2.0 \%$, defatted soybean meal $2.0 \%, \mathrm{NaCl}$ $0.25 \%, \mathrm{CaCO}_{3} 0.35 \%, \mathrm{CuSO}_{4} \cdot 5 \mathrm{H}_{2} \mathrm{O} 0.0005 \%, \mathrm{MnCl}_{2} \cdot 4 \mathrm{H}_{2} \mathrm{O} 0.0005 \%, \mathrm{ZnSO}_{4} \cdot 7 \mathrm{H}_{2} \mathrm{O} 0.005 \%$, $\mathrm{pH} 7.4$ before sterilization. When cultured in this medium with or without yeast extract $0.5 \%$ or corn steep liquor $0.5 \%$, addition of $0.05 \mathrm{ml}$ of the twice diluted culture filtrate taken after 5 days on a reciprocating shaking machine at $27^{\circ} \mathrm{C}$, showed from 50 to $65 \%$ inhibition of the enzyme which catalysed the transfer of the ${ }^{3} \mathrm{H}$-methyl group from ${ }^{3} \mathrm{H}$-methyl-labeled S-adenosyl- 
methionine to one of catechol hydroxyl groups of epinephrine.

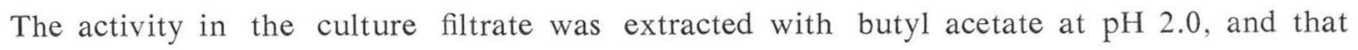
in the mycelial cake was extracted with methanol. The methanol was evaporated under reduced pressure, and the activity in the concentrate was extracted with butyl acetate at $\mathrm{pH}$ 2.0. Butyl acetate extracts thus obtained were combined and evaporated under reduced pressure, yielding a brownish oily material. After washing with petroleum ether, the residue was dissolved in acetone and the acetone solution was evaporated and dried to a brownish powder. It was dissolved in benzene-acetone $(10: 1)$ and subjected to silica gel column chromatography developed with the same solvent. Then, the presence of three active materials was clarified. The compound I which appeared in the earliest active peak was crystallized from acetone- $n$-hexane to give pale yellowish needles, m.p. $176^{\circ} \mathrm{C}$. The compound II in the second active peak was crystallized from hot benzene to give pale yellowish needles, m.p. $197 \sim 198^{\circ} \mathrm{C}$. The compound III which was most slowly eluted was crystallized from acetone- $n$-hexane to give colorless needles, m.p. $215^{\circ} \mathrm{C}$.

These compounds were soluble in alkaline water, methanol, acetone, slightly soluble in butanol, ethyl acetate, butyl acetate. The Rf values on a thin-layer chromatography using silica gel were as follows: I 0.30 , II 0.25 and III 0.19 with benzene-acetone (5: 1); I 0.50 , II 0.30 , III 0.31 with chloroform-methanol $(40: 1)$; I 0.65 , II 0.60 , III 0.50 with benzeneethyl acetate $(1: 1)$.

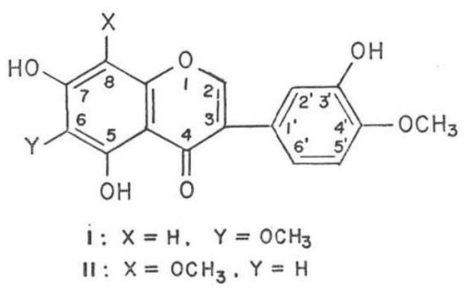

Compound I has molecular formula $\mathrm{C}_{17} \mathrm{H}_{14} \mathrm{O}_{7}$ (MW 330.28). Found: $\mathrm{C}, 61.92 ; \mathrm{H}$, 4.31; O, 33.28. Calcd.: C, 61.82; H, 4.27; $\mathrm{O}, 33.91 . \mathrm{M}^{+}, m / e$ 330. $\nu_{\mathrm{KB}}: 3500,1655,1630$, $1580,1520,1480,830$ and $815 \mathrm{~cm}^{-1} \cdot \lambda_{\mathrm{max}}^{\mathrm{E} \text { OH }}$ $(\log \varepsilon): 269 \mathrm{~nm}(4.31)$ and $295 \mathrm{~nm}$ (shoulder).

Compound II has molecular formula $\mathrm{C}_{17} \mathrm{H}_{14} \mathrm{O}_{7}$ (MW 330.28). Found: $\mathrm{C}, 61.63 ; \mathrm{H}$, 4.50; O, 34.31. Calcd.: C, 61.82; H, 4.27; O, 33.91. $\mathrm{M}^{+}, m / e$ 330. $\nu_{\mathrm{KBr}}$ : 3450, 1655, 1620, $1580,1515,825$ and $810 \mathrm{~cm}^{-1} . \lambda_{\max }^{\mathrm{E} \text { toH }}(\log \varepsilon): 269 \mathrm{~nm}(4.31)$ and $295 \mathrm{~nm}$ (shoulder).

Compound III has molecular formula $\mathrm{C}_{18} \mathrm{H}_{18} \mathrm{O}_{7}$ (MW 344.31). Found: C, 62.86; H, 4.79; O, 32.35. Calcd.: C, 62.79; H, 4.68; O, 32.53. $\mathrm{M}^{+}, \mathrm{m} / \mathrm{e} 344 . \nu_{\mathrm{KBr}}$ : 3500, 1650 (shoulder), $1615,1580,1515,865$ and $854 \mathrm{~cm}^{-1} . \lambda_{\max }^{\mathrm{E} \text { Oㅐ }}(\log \varepsilon): 268 \mathrm{~nm}(4.31)$ and $295 \mathrm{~nm}$ (shoulder).

The preliminary chemical studies suggested that they were structurally related compounds. By oxidative degradation with alkaline hydrogen peroxide they gave 3-hydroxy-4-methoxybenzoic acid which was identified by direct comparison of IR spectra with an authentic sample. The UV spectra suggested that they would have isoflavone structures rather than flavone, and the NMR spectra indicated a singlet proton signal at $\delta 8.3 \sim 8.4$ in hexadeuterodimethylsulfoxide $\left(\right.$ DMSO- $\left.\mathrm{d}_{8}\right)$, which was characteristic to $\mathrm{C}_{2}$-proton in isoflavone compounds.

Compound I gave positive ferric chloride (dark blue) and Gibss (violet) tests for the phenolic hydroxyl group. The NMR spectrum in DMSO- $_{6}$ showed the presence of two methoxyl groups at $\delta 3.78$ and 3.82 , three hydroxyl protons at $\delta 13.04$ (singlet, hydrogen bonded), $c a$. 10.8 and 9.1, the $\mathrm{C}_{2}$-proton at $\delta 8.33$, a singlet proton on A-ring at $\delta 6.52$ and three aromatic 


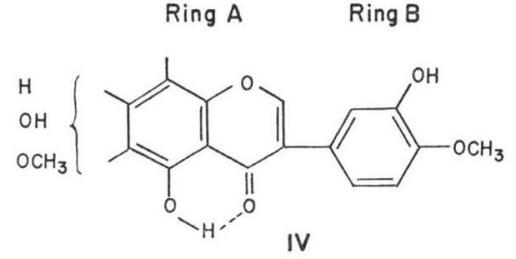

protons on B-ring at $\delta 7.05(1 \mathrm{H})$ and $6.97(2 \mathrm{H})$. These results, isolation of 3-hydroxy-4-methoxybenzoic acid after the oxidative degradation, and the molecular formula indicated the partial structure IV for compound I.

Compound I afforded the triacetyl derivative, m.p. $159^{\circ} \mathrm{C}$, by acetylation with acetic anhydride and sulfuric acid, and the trimethyl ether, m.p. $185^{\circ} \mathrm{C}$, by treatment with dimethyl sulfate. Five methoxyl peaks in the NMR spectrum of the latter in deuterochloroform $\left(\mathrm{CDCl}_{3}\right)$ appeared at $\delta 3.96(6 \mathrm{H}), 3.92(6 \mathrm{H})$ and $3.89(3 \mathrm{H})$ and shifted to $\delta 4.02,3.74,3.52,3.44$ and 3.17 when hexadeuterobenzene (benzene- $\mathrm{d}_{6}$ ) was used as the solvent. This solvent shift is consistent with a 5,6,7-oxygenation pattern in ring $\mathrm{A}$ as reported by WiLSON et al. ${ }^{10)}$ and Sidwell et al. ${ }^{11)}$. Nuclear Overhauser effect was observed between the aromatic proton $\left(\delta 6.28\right.$, benzene- $\left.\mathrm{d}_{6}\right)$ of A-ring and one of the methoxyl signals $\left.(\delta 3.17),+30.3 \% \mathrm{CH} \mathrm{OCH}_{3}\right\}$, in the latter spectrum. The result suggested the presence of the aromatic proton at the 8 position. Addition of aluminium chloride and anhydrous sodium acetate caused a red shift of the main UV absorption band by 15 and $9 \mathrm{~nm}$ respectively. These properties are characteristic of hydroxyl groups at 5 and 7 positions ${ }^{12)}$. From the data described above, the structure of $\mathbf{I}$ can deduced to be 3', 5, 7-trihydroxy-4', 6-dimethoxyisoflavone.

Compound II gave positive ferric chloride (dark blue) and GibBs (violet) tests. The NMR spectrum in DMSO- $\mathrm{d}_{6}$ showed the presence of two methoxyl groups at $\delta 3.78$ and 3.81 , three hydroxyl protons at $\delta 12.60$ (singlet, hydrogen bonded), $c a .10 .8$ and 9.0 , the $\mathrm{C}_{2}$-proton at $\delta 8.40$ and a singlet proton on A-ring at $\delta 6.33$ and three aromatic protons on B-ring at $\delta 7.06(1 \mathrm{H})$ and $6.97(2 \mathrm{H})$. These results and isolation of 3-hydroxy-4-methoxybenzoic acid after oxidative degradation suggested the partial structure IV for compound II. Compound II gave the triacetyl derivative, m.p. $144^{\circ} \mathrm{C}$, and the trimethyl ether, m.p. $163^{\circ} \mathrm{C}$. Five methoxyl peaks in the NMR spectrum of the latter in $\mathrm{CDCl}_{3}$ appeared at $\delta 4.01,3.98,3.93(6 \mathrm{H})$ and 3.91 and shifted to $\delta 3.78,3.50,3.47,3.43$ and 3.26 when benzene- $d_{6}$ was used as the solvent. This solvent shift is consistent with a 5,7,8-oxygenation pattern in ring $\mathrm{A}^{10,11)}$. Nuclear OverHaUser effect was observed between the aromatic proton $\left(\delta 6.00\right.$, benzene- $\left.\mathrm{d}_{b}\right)$ of A-ring and the methoxyl signal at $\delta 3.26,+14.3 \% \mathrm{CH}\left\{\mathrm{OCH}_{3}\right\}$, and another methoxyl signal at $\delta 3.50,+13.6 \% \mathrm{CH}\left\{\mathrm{OCH}_{3}\right\}$, in the latter spectrum. The results suggested the presence of the aromatic proton at the 6 (or 7) position. Addition of aluminium chloride and anhydrous sodium acetate caused a red shift of the main UV absorption band by 16 and $10 \mathrm{~nm}$ respectively. These properties are characteristic to hydroxyl groups at 5 and 7 positions ${ }^{12)}$. Then the structure of II was deduced to be 3', 5, 7-trihydroxy-4', 8-dimethoxyisoflavone.

Compound III gave negative ferric chloride and positive GibBs (blue) tests. The NMR

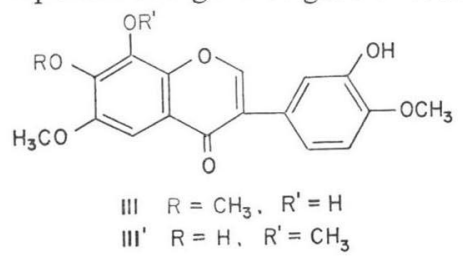
spectrum in DMSO- $\mathrm{d}_{6}$ showed the presence of three methoxyl groups at $\delta 3.90,3.83$ and 3.81 , two hydroxyl protons at $c a . \delta 10.0$ and 9.0 , the $\mathrm{C}_{2}$-proton at $\delta 8.39$, a singlet proton on A-ring at $\delta 7.07$ and three aromatic protons on B-ring 
at $\delta 7.07(1 \mathrm{H})$ and $6.98(2 \mathrm{H})$. There was no hydrogen-bonded hydroxyl proton. Compound III gave the diacetyl derivative, m.p. $165^{\circ} \mathrm{C}$. The NMR spectrum in $\mathrm{CDCl}_{3}$ showed the aromatic proton of A-ring at $\delta 7.58$ (singlet) which was isolated from three aromatic protons of B-ring at $\delta 7.40$ (double doublets, $\mathrm{J}=2.0$ and $8.5 \mathrm{~Hz}$ ), 7.30 (doublet, $\mathrm{J}=2.0 \mathrm{~Hz}$ ) and 7.02 (doublet, $\mathbf{J}=8.5 \mathrm{~Hz}$ ). Nuclear Overhauser effect was observed between the $\delta 7.58$ proton and one of the methoxyl signals (3.98), $\left.+33 \% \mathrm{CH}_{2} \mathrm{OCH}_{3}\right\}$. The result suggested that one of the methoxyl groups is present at ortho position of the $\delta 7.58$ proton. Addition of aluminium chloride did not cause UV shift as expected from negative ferric chloride reaction. On these bases, structure of compound III should be either 3', 8-hihydroxy-4', 6, 7-trimethoxyisoflavone (III, $\mathrm{R}=\mathrm{CH}_{3}, \mathrm{R}^{\prime}=\mathrm{H}$ ) or $3^{\prime}$, 7-hihydroxy-4', 6, 8-trimethoxyisoflavone $\left(\mathrm{III}, \mathrm{R}=\mathrm{H}, \mathrm{R}^{\prime}=\mathrm{CH}_{3}\right.$ ). Addition of anhydrous sodium acetate to ethanolic solution of compound III caused a red shift of the main UV absorption band by $17 \mathrm{~nm}$ which was claimed to be characteristic of 7-hydroxyisoflavones. ${ }^{12)}$ Therefore, we initially preferred 3', 7-dihydroxy-4', 6, 8-trimethoxyisoflavone structure for the compound III. Alternative structure, 3', 8-dihydroxy-4', 6, 7-trimethoxyisoflavone, however, has not been excluded. The $3^{\prime}$, 7-dihydroxy-4', 6, 8-trimethoxyisoflavone $\left(\mathbf{I I I}^{\prime}, \mathrm{R}=\mathrm{H}\right.$, $\mathrm{R}^{\prime}=\mathrm{CH}_{3}$ ) has now been synthesized by $\mathrm{H}$. Suginome et al., the details of which will be reported in a forthcoming paper, ${ }^{13)}$ and it was found that the synthetic compound was not identical with the natural compound III. Therefore compound III should be correctly formulated as 3', 8-dihydroxy-4', 6, 7-trimethoxyisoflavone (III, $\mathrm{R}=\mathrm{CH}_{3}, \mathrm{R}^{\prime}=\mathrm{H}$ ). This was confirmed by a direct comparison of dimethyl ether of the compound (III) and dimethyl ether of the synthetic 3' 7-dihydroxy-4', 6, 8-trimethoxyisoflavone, which proved that two dimethyl derivatives were identical.

Compounds I, II and III are new species of isoflavones which were isolated from streptomyces for the first time. A structure of the compound $\mathbf{I}$ was once reported by Morita et al ${ }^{14)}$, but these authors' product was not identical with $\mathbf{I}$. Hence, it should have a different structure.

Compounds I, II and III inhibited catechol-O-methyltransferase strongly in vitro. The ID $_{50}$ was $0.70 \mu \mathrm{g} / \mathrm{ml}\left(2.11 \times 10^{-6} \mathrm{M}\right), 2.0 \mu \mathrm{g} / \mathrm{ml}\left(6.00 \times 10^{-6} \mathrm{M}\right)$ and $0.2 \mu \mathrm{g} / \mathrm{ml}\left(5.81 \times 10^{-7} \mathrm{M}\right)$, respectively. Their methylated drivatives did not show any inhibition at $100 \mu \mathrm{g} / \mathrm{ml}$, but their acetylated derivatives showed $50 \%$ inhibition at $70 \mu \mathrm{g} / \mathrm{ml}\left(1.55 \times 10^{-4} \mathrm{M}\right), 1.6 \mu \mathrm{g} / \mathrm{ml}\left(3.55 \times 10^{-6} \mathrm{M}\right)$ and 1.0 $\mu \mathrm{g} / \mathrm{ml}\left(2.15 \times 10^{-6} \mathrm{M}\right)$ respectively.

The kinetics were studied using the enzyme which was partially purified by a modified method described by BALL and his associates. ${ }^{4)}$ The results are shown in Table 1. Compound I showed non-competitive type of inhibition, but compounds II and III showed mixed type of inhibition against epinephrine as substrate. Non-competitive type of inhibition was obtained against S-adenosylmethionine with these three compounds. Very little change of inhibition was observed under various concentrations of magnesium ions, from $3.1 \times 10^{-4} \mathrm{M}$ to $2.0 \times 10^{-2} \mathrm{M}$.

The effects of compounds I, II and III on tyrosine hydroxylase, dopa decarboxylase and dopamine $\beta$-hydroxylase were also studied. In the reaction mixture described by LovENBERG ${ }^{15}$ preparing the enzyme solution as described by DAvis and AWAPARA ${ }^{18)}$, dopa decarboxylase was inhibited by $5.0 \mu \mathrm{g} / \mathrm{ml}\left(1.52 \times 10^{-5} \mathrm{M}\right)$ ( ID $\left._{50}\right)$ of compound II and by $12.5 \mu \mathrm{g} / \mathrm{ml}\left(3.79 \times 10^{-5} \mathrm{M}\right)$ of compound I but not by compound III $(100 \mu \mathrm{g} / \mathrm{ml})$. The compounds I and II inhibited histidine decarboxylase prepared from rat embryo in the reaction mixture as described previously ${ }^{17}$ : 
$50 \%$ inhibition concentration of I was $1.8 \times 10^{-5} \mathrm{M}$ and that of II was $4.5 \times 10^{-8} \mathrm{M}$. They did not inhibit the other enzymes at $100 \mu \mathrm{g} / \mathrm{ml}$. The intravenous administration of $200 \mathrm{mg} / \mathrm{kg}$ of each substance to mice did not show any toxic sign. Antimicrobial activity of these compounds was not observed at $100 \mu \mathrm{g} / \mathrm{ml}$.

Table 1. Inhibition of catechol-O-methyltransferase by compounds I, II and III

\begin{tabular}{|c|c|c|c|c|}
\hline & \multicolumn{4}{|c|}{ Substrate } \\
\hline & \multicolumn{2}{|c|}{$\begin{array}{c}\text { Epinephrine } \\
\left(\mathrm{Km}=8.3 \times 10^{-4} \mathrm{M}\right)\end{array}$} & \multicolumn{2}{|c|}{$\begin{array}{l}\text { S-Adenosylmethionine } \\
\quad\left(\mathrm{Km}=1.3 \times 10^{-4} \mathrm{M}\right)\end{array}$} \\
\hline & Type of inhibition & $\mathrm{Ki}$ & Type of inhibition & $\mathrm{Ki}$ \\
\hline I & non-competitive & $1.7 \times 10^{-6} \mathrm{M}$ & non-competitive & $1.7 \times 10^{-6} \mathrm{M}$ \\
\hline II & mixed & $3.3 \times 10^{-6} \mathrm{M}$ & non-competitive & $9.1 \times 10^{-8} \mathrm{M}$ \\
\hline III & mixed & $1.5 \times 10^{-7} \mathrm{M}$ & non-competitive & $3.9 \times 10^{-7} \mathrm{M}$ \\
\hline
\end{tabular}

Measurement of catechol-O-methyltransferase activity was carried out by the modified method of Nikodejevic et al..$^{9)}$ The concentrations of epinephrine were varied from $1.6 \times 10^{-4} \mathrm{M}$ to $2.5 \times$ $10^{-3} \mathrm{M}$ under the concentration of $7.5 \times 10^{-4} \mathrm{M}$ of S-adenosylmethionine. Similarly, the concentrations of S-adenosylmethionine were varied from $4.7 \times 10^{-5} \mathrm{M}$ to $7.5 \times 10^{-4} \mathrm{M}$ under the concentration of $2.5 \times 10^{-3} \mathrm{M}$ of epinephrine.

Fig. 1. Effect of intraperitoneal injection of compound I on blood pressure of SH-rats Mean depression percentage (4 rats) of each dose Bars show the standard error of 4 rats.

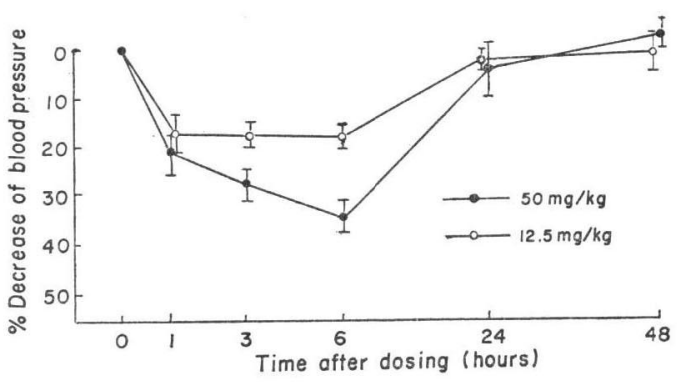

Fig. 2. Effect of intraperitoneal injection of compound II on blood pressure of SH-rats Mean depression persentage (4 rats) of each dose Bars show the standard error of 4 rats.

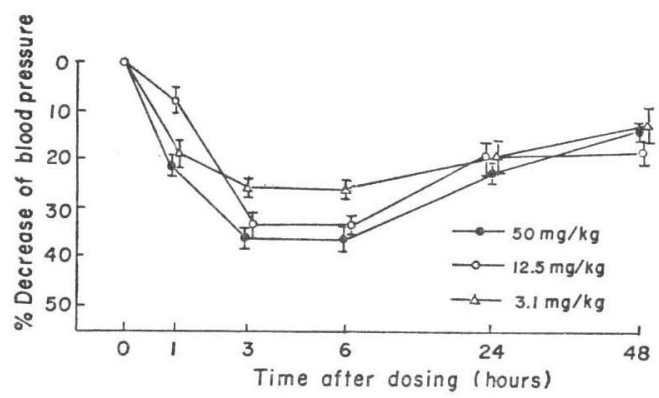

Hypotensive effect was shown by the compounds I and II, and the latter showed a strong effect. When $50 \mathrm{mg} / \mathrm{kg}$ of $\mathbf{I}$ was intraperitoneally injected to spontaneously hypotensive rats (4 rats were injected in each dose), the percent blood pressure decrease after various hours of the injection compared with the pressure before the injection is shown in Figs. 1 and 2 . The marked decrease in blood pressure was observed $3 \sim 6$ hours after the injection of both compounds. The compound II showed the stronger effect than the compound I and the significant decrease was shown even by $3.1 \mathrm{mg} / \mathrm{kg}$ during $3 \sim 24$ hours after the injection. The intraperitoneal injection of $50 \mathrm{mg} / \mathrm{kg}$ of III did not show a significant decrease of blood pressure. As described above, among compounds I, II, and III, the activity inhibiting catechol-O-methyltransferase was the strongest in III and II showed the strongest activity in inhibiting dopa decarboxylase. It suggests that inhibition of catechol-O-methyltransferase would not be related to the hypotensive action, but inhibition of dopa decarboxylase might be the reason for the hypotensive effect. 
As described in this paper, we found three new isoflavones in streptomyces culture filtrate. Such compounds could not be found in media before inoculation of the strain ISP 5174. However, it is not certain whether streptomyces can synthesize the isoflavone skeleton de novo. It is possible that isoflavone compounds in medium ingredients such as soybean meal might be converted to the compounds I, II and III by streptomyces.

\section{Experimental}

Equipments for physical determination:

UV was measured by Hitachi UV spectrometer EPS-3T, IR by Hitachi Infrared spectrometer EPI-S2, NMR by Varian HA-100D, mass analysis by Hitachi RMU-6M.

Method of assay for activity inhibiting catechol-O-methyltransferase:

The reaction mixture consisted of distilled water $0.125 \mathrm{ml}, 0.1 \mathrm{M}$ phosphate buffer at $\mathrm{pH}$ $8.00 .05 \mathrm{ml}, 0.1 \mathrm{M} \mathrm{MgCl}_{2} 0.1 \mathrm{ml}, 0.05 \mathrm{M}$ epinephrine $0.05 \mathrm{ml}, 0.05 \mathrm{~mm}{ }^{3} \mathrm{H}$-methyl-labeled S-adenosylmethionine $\left(2.2 \times 10^{5} \mathrm{cpm}\right) 0.075 \mathrm{ml}$, a test sample or distilled water $0.05 \mathrm{ml}$, the enzyme solution $0.05 \mathrm{ml}$. The reaction mixture except enzyme was mixed at $0{ }^{\circ} \mathrm{C}$ and the reaction was started after addition of the enzyme solution and the incubation at $37^{\circ} \mathrm{C}$ was continued for 20 minutes. The reaction was stopped by addition of $1.0 \mathrm{ml}$ of $0.5 \mathrm{M}$ borate buffer at $\mathrm{pH} 10.0$ and the reacted mixture was extracted with toluene-isoamylalchohol $(3: 2)$ and the radioactivity in the solvent layer was counted by Beckmann sintillation counter LS- 250.

The enzyme solution was prepared from rat liver. It was homogenized with 3 volume of $0.25 \mathrm{M}$ sucrose and centrifuged at $105,000 \mathrm{~g}$. This supernatant was divided into each $2 \mathrm{ml}$ and kept in frozen. Before use, it was diluted 10 times with distilled water and employed. Epinephrine solution was prepared as follows: $832.5 \mathrm{mg}$ of epinephrine bitartarate (purchased from Tokyo Kasei Co.) was dissolved in $50 \mathrm{ml}$ of $0.1 \mathrm{~N} \mathrm{HCl}$ and $\mathrm{pH}$ was adjusted to 5.0 and kept in frozen. The percent inhibition was calculated from the radioactivity as follows $\left(1-\frac{A-C}{B-C}\right)$ $\times 100$, where $B$ is that without inhibitor, $A$ is that with inhibitor and $C$ is that without the enzyme. The culture filtrate was heated at $100^{\circ} \mathrm{C}$ for 3 minutes before assay.

For kinetic study, catechol-O-methyltransferase was purified as follows: Rat liver $(31.25 \mathrm{~g})$ was homogenized with 2 volumes of $0.25 \mathrm{M}$ sucrose and centrifuged at $105,000 \mathrm{~g}$ for 1 hour. The supernatant was made $\mathrm{pH} 5.0$ by addition of acetic acid and the precipitate was removed by 10 minutes centrifugation at $10,000 \mathrm{~g}$. To this supernatant $0.5 \mathrm{M}$ phosphate buffer at $\mathrm{pH} 7.8$ was added until $\mathrm{pH}$ became 6.8 (the total volume became $61 \mathrm{ml}$ ). To this solution $10.7 \mathrm{~g}$ of ammonium sulfate was added and the precipitate was removed by centrifugation at $10,000 \mathrm{~g}$ for 10 minutes. To the supernatant $15.3 \mathrm{~g}$ of ammonium sulfate (to $65 \%$ saturation) was added and centrifuged at $10,000 \mathrm{~g}$ for 20 minutes. The precipitate was dissolved in $2 \mathrm{~mm}$ phosphate buffer $(11.5 \mathrm{ml})$ at $\mathrm{pH} 7.4$ and sujected to Sephadex G 100 column $(3 \times 70 \mathrm{~cm})$ chromatography developed with the same buffer. The effluent was cut into each $5 \mathrm{~g}$, and the active effluent (from 20th to 28 th fractions) was passed through CM-Sephadex column $(2 \times 6 \mathrm{~cm})$ equilibrated with $2 \mathrm{~mm}$ phosphate buffer at $\mathrm{pH}$ 6.7. The effluent was collected in 4-ml fractions. The active fractions (3rd 10th fractions) were collected. About 20 fold purification was accomplished by this method. This partially purified enzyme solution was employed for the kinetic study.

Extraction and isolation of compounds I, II, and III:

S. roseolus ISP 5174 was shake-cultured in a medium containing glucose $1.0 \%$, starch $2.0 \%$, defatted soybean meal $2.0 \%, \mathrm{NaCl} 0.25 \%, \mathrm{CaCO}_{3} 0.35 \%, \mathrm{CuSO}_{4} \cdot 5 \mathrm{H}_{2} \mathrm{O} 0.0005 \%, \mathrm{MnCl}_{2} \cdot 4 \mathrm{H}_{2} \mathrm{O}$ $0.0005 \%, \mathrm{ZnSO}_{4} \cdot 7 \mathrm{H}_{2} \mathrm{O} 0.005 \%(\mathrm{pH} 7.4$ before sterilization). After 3 days shaking culture at $27^{\circ} \mathrm{C}, 500 \mathrm{ml}$ of the culture broth was inoculated to 12 liters of the same medium placed in a jar fermentor and $1.2 \mathrm{ml}$ of silicone resin was added to suppress the foaming. The fermentation was continued for 105 hours at $27^{\circ} \mathrm{C}$ under aeration of 12 liters/minute and $250 \mathrm{rpm}$ stirring. The culture broth of 4 fermentors was combined and centrifuged at 2,500 rpm. The 
liquid part (40 liters) and the wet solid part $(5 \mathrm{~kg})$ were thus separated. The wet solid was extracted with 5 liters of methanol. Addition of $0.05 \mathrm{ml}$ of the 4 times diluted methanol solution (4.8 liters) or of the twice diluted culture filtrate to the reaction mixture for assay of an inhibitor of catechol-O-methyltransferase showed $50 \%$ inhibition. This methanol solution was concentrated to $500 \mathrm{ml}$ under reduced pressure and added to the liquid part of the culture broth and extracted with 40 liters of butyl acetate at $\mathrm{pH}$ 2.0. The evaporation of the butyl acetate solution under reduced pressure gave $80 \mathrm{~g}$ of oily material. It was washed with petroleum ether yielding $35.0 \mathrm{~g}$ of brown powder ( $\mathrm{ID}_{50}=111 \mu \mathrm{g}$ ). The powder was dissolved in $300 \mathrm{ml}$ of acetone and the insoluble part was removed. To the acetone solution, $90 \mathrm{~g}$ of silica gel (Mallinckrodt, Silicic Acid AR 100 mesh) was added and dried under reduced pressure. This powder was placed on the top of the silica gel column $(6.5 \times 58.0 \mathrm{~cm})$, and the column was developed with the same solvent. A yellow powder $(790 \mathrm{mg})$ containing compound I was obtained by evaporation of the first active fraction $(800 \mathrm{ml})$ under reduced pressure. Another active yellow powder $(250 \mathrm{mg})$ containing compound II was obtained from the second active eluate $(1,500 \mathrm{ml})$ and the active brown powder $(150 \mathrm{mg})$ containing compound III was obtained from the third active fraction $(1,500 \mathrm{ml})$. These powders showed $50 \%$ inhibition of catecholO-methyltransferase in the following doses: I powder $20 \mu \mathrm{g}$; II powder $50 \mu \mathrm{g}$; III powder $2.0 \mu \mathrm{g}$.

The I powder was dissolved in $10 \mathrm{ml}$ of methanol and passed through Sephadex LH-20 $(500 \mathrm{ml})$. The activity appeared in one peak $(25 \mathrm{ml})$ and the eluate was evaporated to dryness under reduced pressure. The powder was dissolved with $5 \mathrm{ml}$ of acetone and $20 \mathrm{ml}$ of $n$-hexane was added. After overnight, I crystallized: $18.5 \mathrm{mg}$ of pale yellow needle crystals.

The II powder described above was subjected to Sephadex LH-20 chromatography similar to that described above. The powder thus obtained was dissolved in $4 \mathrm{ml}$ of benzene at $60^{\circ} \mathrm{C}$. Then, after 1 week at room temperature, $20 \mathrm{mg}$ of II crystals was obtained.

The III powder described above was mixed with 3 times weight of alumina and placed in a column and the compound III was dissolved in methanol which was passed through the column. The brown-colored impurity was removed by this method. The methanol solution was passed through Sephadex LH-20 column $(500 \mathrm{ml})$ and the active eluate was evaporated to dryness. The crystallization by the same method as used for compound I gave $11.5 \mathrm{mg}$ of colorless needle crystals of III.

Method of measuring the activity in inhibiting dopa decarboxylase ${ }^{15,18)}$ : The reaction mixture consisted of L-dopa $1 \times 10^{-3} \mathrm{M}$, pyridoxal phosphate $7.5 \times 10^{-5} \mathrm{M}, 0.05 \mathrm{ml}$ of dopa decarboxylase solution, phosphate buffer $\left(\mathrm{pH}\right.$ 6.9) $0.03 \mathrm{M}$, iproniazid $1 \times 10^{-3} \mathrm{M}, 0.1 \mathrm{ml}$ of a test material, and the total volume was made $1.5 \mathrm{ml}$ with distilled water. The reaction was started by addition of the enzyme solution. The incubation time at $37^{\circ} \mathrm{C}$ was 25 minutes. The reaction was stopped by heating at $100^{\circ} \mathrm{C}$ for 3 minutes. The reacted solution was passed through Amberlite CG-50 column $(0.5 \times 7.5 \mathrm{~cm})$ and dopamine adsorbed was eluted with $1.5 \mathrm{ml}$ of $1 \mathrm{~N}$ acetic acid. The optical density at $279 \mathrm{~nm}$ of the eluate was read.

Dopa decarboxylase was prepared from rat liver. It was homogenized with 2 volumes of $0.003 \mathrm{~m}$ mercaptoethanol. The homogenate was centrifuged at $13,000 \mathrm{rpm}$ for 20 minutes, and the precipitate was obtained by $0.45 \sim 0.55$ saturation of ammonium sulfate. It was dissolved in $0.003 \mathrm{M}$ mercaptoethanol. The concentration of the enzyme solution was adjusted as its addition of $0.05 \mathrm{ml}$ gave optical density 0.3 of dopamine. Generally, the protein content of this enzyme solution was $1.0 \mathrm{mg} / \mathrm{ml}$.

Testing the hypotensive effect: Four spontaneously hypertensive rats (male) of $15 \sim 20$ weeks age were employed for each dosis. One, 3, 6, 24 and 48 hours of intraperitoneal injection of $50 \mathrm{mg} / \mathrm{kg}$ or $12.5 \mathrm{mg} / \mathrm{kg}$ of compound $\mathbf{I}, 50 \mathrm{mg} / \mathrm{kg}, 12.5 \mathrm{mg} / \mathrm{kg}$ or $3.1 \mathrm{mg} / \mathrm{kg}$ of compound II and $50 \mathrm{mg} / \mathrm{kg}$ of compound III, the blood pressure was measured by the plethysmographic tail method. Percent decrease from the pressure before injection was calculated (Figs. 1 and 2). 


\section{References}

1) Axelrod, J. \& R. Tомсніск: Enzymatic O-methylation of epinephrine and other catechols. J. Biol. Chem. 233: 702 705, 1958

2) Assicot, M. \& C. Bohuon: Purification and studies of catechol-O-methyltransferase of rat liver. Eur. J. Biochem. 12: 490 495, 1970

3) Flohe, K. \& K.P. Schwabe: Kinetics of purified catechol-O-methyltransferase. Biochim. Biophys. Acta 220: 469 476, 1970

4) Ball, P.; R. KNuppen \& H. Breuer: Purification and properties of a catechol-O-methyltransferase of human liver. Eur. J. Biochem. 21: 517 525, 1971

5) Borchardt, R. T.: Catechol-O-methyltransferase: 1. Kinetics of tropolone inhibition. J. Med. Chem. 16: 377 382, 1973

6) Gugler, R. \& H. J. Dengler: Inhibition of human rat liver catechol-O-methyltransferase by flavonoids. Naunyn-Schmiedeberg's Arch. Pharmacol. 276: 223 233, 1973

7) Chimura, H.; T. Sawa, T. Takita, M. Matsuzaki, T. Takeuchi, T. Nagatsu \& H. Umezawa: Methylspinazarin and dihydromethylspinazarin, catechol-O-methyltransferase inhibitors produced by Streptomyces. J. Antibiotics 26: 112 114, 1973

8) Chimura, H.; T. Sawa, Y. Kumada, F. Nakamura, M. Matsuzaki, T. Takita, T. Takeuchi \& H. UMEzAwA: 7-O-Methylspinochrome B and its 6-(3-hydroxy- $n$-butyl)-derivative, catechol-Omethyltransferase inhibitors, produced by Fungi imperfecti. J. Antibiotics 26: 618 620, 1973

9) Nikodejevic, B.; S. Senoh, J. W. Daly \& C. R. Creveling: Catechol-O-methyltransferase. II. A new class of inhibitors of catechol-O-methyltransferase; 3, 5-dihydroxy-4-methoxy benzoic acid and related compounds. J. Pharmacol. Exp. Ther. 174: 83 93, 1970

10) Wilson, R. G.; J.H. Bowie \& D. H. Williams: Solvent effects in NMR spectroscopy. Solvent shifts of methoxyl resonances in flavones induced by benzene; an aid to structure elucidation. Tetrahedron 24: 1407 1414, 1968

11) Sidwell, W. T. L. \& Ch. ТАмм: The homo-isoflavones. II. Isolation and structure of 4'-Omethyl-punctatin, autumnalin and 3,9-dihydroautumnalin. Tetrahedron Letters 1970-7: 475 478, 1970

12) Horowitz, R. M. \& L. Jurd: Spectral studies on flavonoid compounds. II. Isoflavones and flavanones. J. Org. Chem. 26: 2446 2449, 1961

13) Suginome, H.; H. Takahashi, H. Kuramoto \& T. Masamune: to be published.

14) Morita, N.; M. Shimokoriyama, M. Shimizu \& M. Arisawa: Studies on medicinal resources. XXXII. The components of rhizome of Iris tectorum Maximowicz (Iridaceae). Chem. Pharm. Bull. 20: $730 \sim 733,1972$

15) Lovenberg, W.; H. Weissbach \& S. Udenfriend: Aromatic L-amino acid decarboxylase. J. Biol. Chem. 237: 89 93, 1962

16) Davis, V.E. \& J. Awapara: A method for the determination of some amino acid decarboxylases. J. Biol. Chem. 235: 124 127, 1960

17) Umezawa, H.; N. Shibamoto, H. Naganawa, S. Ayukawa, M. Matsuzaki, T. Takeuchi, K. Kono \& T. SAKAmoto: Isolation of lecanoric acid, an inhibitor of histidine decarboxylase from a fungus. J. Antibiotics 27: 587 596, 1974 